Галина МИЛЕНЬКА

\title{
«DIGNUS EST INTRARE»: СПЕЦИФIКА АКТОРСЬКОГО МИСТЕЦТВА У ПОГЛЯДАХ БЕНУА-КОНСТАНА КОКЛЕНА
}

У статті систематизовано міркування Б.-К. Коклена в галузі естетики сиенічного мистеитва, які репрезентують принципи акторської «школи удавання». Розглянуто як погляди Коклена на специфіку акторської творчості, так і його позииію щчодо співвідношення мистецтва і природи, умовності і правдоподібності, почуття та розуму в акторському мистеитві.

Ключові слова: акторське мистецтво, «школа удавання», сиенічний образ, психофізика актора, самовладання, умовність сиенічного мистецтвв.

В статье систематизированы высказывания Б.-К. Коклена в области эстетики сиенического искусства, в которых раскрываются приниипы актерской «школы представления». Рассмотрены, как взгляды Коклена на специфику актерского творчества, так и на проблемы соотношения искусства и природы, условности и правдоподобности, чувства и рассудка в актерском искусстве.

Ключевые слова: акторское искусствол, «школа представления», сиенический образ, психофизика актера, самообладание, условность сиенического искусства.

The article systematizes the considerations of B.-C. Coquelin in the field of aesthetics of performing arts that represent the principles of acting "school of representation». The author considers the views of Coquelin on the specificity of actor's art and his position regarding the relationship between art and nature, conventionality and credibility, emotions and mind in acting.

Keywords: acting art, "school of representation», stage image, psychophysics, emotions, self-control, conventionality of stage art.

Традиція сприйняття актора як комедіанта проіснувала у Франції аж до кінця XIX ст., і це попри те, що французька сцена вже була уславлена блискучими іменами Жана Батиста Мольєра, Марі Шанмелє, Кристини Демар, Марі Дюкло, Мішеля Барона, Анрі Луї Лекена, Марі Дюменіль, Іпполіти Клерон, естафету слави котрих у XIX ст. підхопили Жан-Муне Сюллі, Сара Бернар, Батист Констан Бенуа та ін. Однією з позицій дискримінації акторської професії було невизнання на державному рівні суспільної значущості сценічної діяльності. Так, орден Почесного легіону, як і інші знаки офіційної пошани, не могли бути вручені акторам, на відміну від представників інших мистецьких професій. Проти несправедливого ставлення до майстрів сцени однією 3 перших, хто відкрито розпочав боротьбу за права акторів та визнання їхньої суспільної місії, стала Іпполіта Клерон (1723-1803). Нехтування з боку державних інститутів iï вимогами змусило актрису, на знак протесту, у розквіті свого блискучого таланту і надзвичайного успіху у публіки піти зі сцени.

У другій половині XIX ст. проблему суспільного визнання та зрівняння у правах майстрів сцени 3 митцями в галузі інших видів мистецтва ініціює Бенуа Констан Коклен (1841-1909), котрий увійшов в історію театру не лише як актор, а й як автор низки теоретичних праць і статей, присвячених питанню сценічної творчості. У своїх есе «Мистецтво і актор» (1880) та «Мистецтво актора» (1886) Коклен, позиціонуючи професію актора як мистецтво, намагався впровадити у суспільну свідомість те, що актор - такий само митець, як живописець і музикант, а «старорежимні забобони, що відкидали за ним право суспільного визнання, втратили будь-які підстави у наш демократичний час» $[2,21]$. Аргументоване обгрунтування того, що актор, так само як поет, художник, скульптор або музикант, є митцем і що «у державі він має право на таке саме місце, як будь-який громадя- 
нин» [2, 85], відіграло у цій справі вирішальну роль. Логіка аргументів Коклена була неспростовною. Він зауважує, що якщо мистецтво прийнято розуміти як інтерпретацію природи й істини, то акторська діяльність, так само, як і мистецтво живопису, скульптури, музики цілком відповідає цій вимозі. Праці Коклена мали неабиякий резонанс, внаслідок чого майже столітні зусилля акторської братії увінчалися успіхом. Усталена у французькому суспільстві думка, що актор - «усього-но лише папуга» $[2,85]$ та упереджене ставлення до мистецтва сценічного виконавця поступово зникають i, за сподіваннями Коклена «вже не воскреснуть більш ніколи, і актор Мольєр, в особі продовжувачів його справи, може вважатися визнаним Почесним легіоном, як «dignus intrare» (лат. гідний увійти $-\Gamma$. М.) $[2,22]$. Передбачаючи можливі сумніви стосовно того, що акторська праця є творчою, «оскільки думка, яку втілює актор не $\epsilon$ думкою, $[2,86]$ та наявності в акторській професії такої особливості мистецтва як «творення», Коклен спростовує їх загальноприйнятим словосполученням, яке було в обігу вже майже сто років і яке використовували такі визнані теоретики театрального мистецтва, як Ж.Ф. Мармонтель, Вольтер, В.Гюго, а саме: «актор створив роль», що відразу знімало питання з цього приводу.

Визначаючи мистецтво діяльністю творення, у якій «істина наділяється великою долею поетичного вимислу», що суттєво зараджує їі сприйняттю, Коклен розрізняє його види за «інструментами» та «матеріалом» $[2,22]$, що їх використовують для створення мистецького твору. Для художника це відповідно пензель, фарби та полотно, для скульптора - стека, різець та мармур або бронза, для поета - ритм, розмір, рима та слово $[2,22$; 85]. Лише у актора «інструментом» творення та «матеріалом», що він «обробляє і змінює» $[2,22]$ $\epsilon$ він сам. Актор, так само, як і живописець, скульптор чи поет інтерпретує природу, наслідує життя, втілює думки і образи, а різниця полягає лише у тому, що він «ліпить образ з самого себе, як скульптор ліпить 3 глини і живописець накладає фарби на полотно» $[2,85-86]$. «Інструмент» актора його особистість, «матеріал» - обличчя, тіло, досвід, врешті-решт його життя. Таким чином, Коклен неспростовно доводить безпідставність виведення сценічної праці за межі мистецтва, адже, так само, як і визнані на той час його види, творчість актора безпосередньо пов'язана 3 інтерпретацією природи та істини, а відтак - робота над роллю вочевидь $\epsilon$ творчою, а процес народження сценічного образу — процесом творення.
Теоретичні міркування Б.-К. Коклена охоплюють значно ширше коло питань. Зокрема, його увага сконцентрована на виявленні специфіки роботи актора над образом. Так, у есе «Мистецтво і актор» він артикулює свою позицію щодо співвідношення почуття та розуму в акторському мистецтві - одного з найбільш дискусійних питань у галузі сценічної майстерності, яке визначало психофізичне самопочуття актора на сцені. Коклен відзначає, що з цього приводу існує дві думки. Прихильники однієї вважають, що актор повинен «розділяти почуття того персонажа, котрого він грає, - тобто плакати, щоб змусити плакати інших», іншої - актор повинен контролювати себе i безпосередньо не переживати жодного 3 почуттів, що він виражає, навіть тоді, коли його герой доходить до «найбільшого самозабуття» $[2,102]$.

Себе Б.-К. Коклен позиціонує прибічником другого підходу до акторського самопочуття на сцені, перше теоретичне обгрунтування якого було надано Дені Дідро у «Парадоксі про актора» (1773). Теза Дідро, що «найвеличнішим актором $\epsilon$ той, хто глибше вивчив і з найбільшою досконалістю зображує зовнішні ознаки $<$..> задуманого ідеального образу» $[1,176]$, керуючись у своєму мистецтві не почуттям, а розумом, була суголосною 3 його поглядами на сутність сценічної майстерності. Так само, як і автор «Парадоксу про актора», Коклен вважає, що актор може бути великим лише за умови «найповнішого самовладання та здатності за власною волею виражати такі почуття, які не переживаєш, ніколи не будеш переживати й за самою своєю природою не можеш переживати» [2, 102-103], і саме таке співвідношення розуму, волі і почуття прокладає шлях до істинної майстерності актора. На користь свого підходу Б.-К. Коклен наводить доволі переконливий аргумент, порівнюючи роботу над створенням образу актора 3 процесом народження образної системи у праці драматурга і художника. Подібно до того, як «у голові драматурга», котрий у житті може бути найдоброчеснішою і найчеснішою людиною, як то Мольєр або Шекспір, народжуються образи підступних героїв, так і в актора має бути відпрацьована здатність, залишаючись самим собою, «уподібнюватися» за власною волею дійовій особі п'єси. Перебуваючи щомиті в образі, актор одночасно має «залишатися цілком відособленим» від нього на кшталт живописця, який «існує окремо від свого полотна» $[2,104]$. Коклен наголошує на різних алгоритмах функціонування почуттів та свідомості і вважає запорукою успіху у творчій діяльності актора постійне збереження 
ментального контролю під час перебування в образі, що жодним чином не заважає природності прояву почуттів.

Оскільки актор є і суб'єктом і об'єктом свого мистецтва, відмітною рисою його творчості, на думку Коклена, є «роздвоєння» [2, 24], тобто він одночасно - творець (його перше Я) і матеріал (його друге Я) мистецького артефакту. Перше Я актора, виходячи 3 характеру, доби, середовища тощо, віртуально, у своїй свідомості, створюе зовнішній вигляд персонажа, друге Я - реалізує його у просторі. Цей процес триває, доки перше Я не перетворить друге Я на задуманий образ, «доки він не зробить 3 самого себе власний твір мистецтва». Отже, актор має розчинитися у створеному образі: «говорити, діяти, рухатись», як би це робив певний персонаж у певних обставинах, щоб «створити у глядача ілюзію автентичності дійової особи» $[2,24]$. Проте цьому передує ретельне занурення у літературний матеріал, аби проникнути у задум автора, зокрема з'ясувати місце і значення свого героя у драматургічному контексті та змоделювати у своїй уяві ритмо-пластичну та мовно-інтонаційну манеру прояву його індивідуальності. 3 метою надання певної системності роботі над роллю, він виокремлює три початкові етапи процесу народження образу у свідомості актора. Перший - актор осмислює задум драматурга, другий - узгоджує можливі прояви характеру персонажа 3 вимогою природності, третій — використовує власні знання про «людей і речі» та спирається на власний досвід і уяву для наповнення образу живим змістом. Внаслідок цього народжується образ і актор починає бачити свою роль, відчувати іiі, «починає жити в ній: вона належить йому!» $[2,104]$. Але окрім внутрішньої візуалізації образу, коли він формується у свідомості і душі актора, процес творення не завершується, адже «створити душу, зауважує Коклен, - це ще не все: треба помістити ії у тіло» і в такий спосіб,

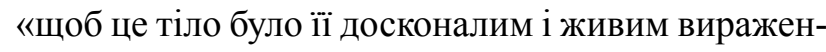
ням» $[2,92]$.

Наступним кроком, за Кокленом, має стати перенесення створеної в уяві моделі образу «на себе самого» подібно до художника, котрий переносить кожну деталь свого задуму на полотно $[2,25]$. Тому далі починається не менш творчий процес роботи над роллю, пов'язаний $з$ пошуками адекватної форми іiї втілення, що іії Коклен називає «шкірою», в яку виконавець одягає роль, «плоттю, якої потребує сценічний образ і яку дає йому актор» $[2,93]$. На цьому етапі роботи актор, так би мовити, «матеріалізує», проявляє назовні за допомогою свого тіла особливості конкретної людської індивідуальності, відпрацьовує притаманну лише їй «манеру ходити, виходити, сідати, сміятися, плакати, зітхати, говорити, мовчати» і то таким чином, щоб «всі ці манери існувати, діяти i страждати були узгоджені» i «складали у сумі людську індивідуальність, реальну <...>, котру можна зустріти <...>, звернутися до неї «на ти» [2, 92-93]. Власне зовнішнє має стати проявом внутрішнього, сценічна форма - характеру й історії персонажа. Наразі Коклен неодноразово наголошував, що турбота про внутрішній зміст образу $\epsilon$ постійним і першочерговим завданням актора, а сценічна зовнішність слугує лише його «ілюстрацією», призначення якої «виявити характер, не викривляючи його перебільшенням» $[2,47]$.

Процес репетицій триває доти, доки «внутрішній критик» актора — його перше Я - не впевниться у максимальній точності реалізації другим Я актора фізичного прояву задуманого образу, власне сценічної форми, яка виявляє характер його персонажа. В такий спосіб, перебуваючи «наче всередині створеного ним образу», через вольове спрямування нервової системи актор зможе «за власним бажанням» $[2,104]$ безпомилково керувати вираженням необхідних проявів почуттів сценічного персонажа. Запорукою успішного існування на сцені в образі, акцентує Коклен, є постійний контроль «вічно незворушного першого Я» за проявом почуттів другого Я актора, але у тих межах, які заздалегідь продумані і встановлені ним. Знайдені та відпрацьовані під час репетицій засоби сценічної виразності мають бути зафіксовані остаточно, і вже від акторської техніки залежить уміння виконавця застосовувати їх для відтворення сценічного образу, у будь-який момент за власною волею. Коклен вважає «помилковим і смішним» думку, що «верх мистецтва полягає у тому, щоб актор забув, що він знаходиться перед публікою»; у такому разі він «вже не актор, він - божевільний!» [2, 59]. Суть акторського мистецтва, за Кокленом, полягає не в ототожненні себе 3 персонажем, а в його удаванні. Послідовно опанувавши етапи акторської роботи над роллю, «справжній актор» завжди буде перебувати у «стані творчої готовності» і це дасть йому можливість розпочинати свою роль 3 будь-якого місця й миттєво відтворювати свого персонажа у будь-якому стані та викликати у глядача потрібне враження $[2,105]$. В такий спосіб актор сам керуватиме пружинами, котрі запускають потрібні у певній сцені почуття персонажа, а не чекатиме натхнення, яке б дало йому змогу їх пережити, аби точно їх від- 
творити. Коклен акцентує складність і виснажливість процесу перебування актора в образі, який, окрім неабиякої сценічної техніки, потребує від сценічного виконавця подолання когнітивного дисонансу і вміння «регулювати витрати енергії» $[2,104]$. На його думку, «тим вище стоїть митець», чим «більш повновладно повеліває його перше Я», тому, попри те, що обидва Я актора є «невіддільними одне від одного, <...> панувати має перше Я — те, яке спостерігає. Воно - душа, а друге Я - тіло» $[2,26]$. Франсуа Жозеф Тальма у своєму есе «Про сценічне мистецтво» (1825) з цього приводу висловлює аналогічну думку, вважаючи, що «у актора натхнення має бути миттєвим і цілком підкорятися його волі < ..>. Крім того, необхідно, щоб ум його завжди був насторожі, щоб завжди діяв узгоджено 3 чутливістю і керував би таким чином діями і афектами» [3, 33-34].

Завдяки контролю розуму, стверджує Коклен, актор панує над власними почуттями і підкорює їх собі [2, 105-106], і його майстерність безпосередньо пов'язана із вмінням брати гору над своїми почуттями. Актор не повинен «бути розчуленим», адже «йому це потрібно не більше, ніж піаністу впасти у відчай для того, щоб зіграти похоронний марш Шопена чи Бетховена!». А актор, котрий ототожнює почуття персонажа із власними переживаннями, обов'язково втрачає самовладання під час виконання ролі й ризикує вийти «за межі» створюваного характеру, що гарантовано зашкодить художній цілісності сценічного образу [2, 107]. Для акторської практики є помилковим покладатися на натхнення, вважає Коклен, яке може й не «ощасливити» своєю присутністю виконавця під час перебування на сцені і без присутності якого бурхливі, а подеколи і «шалені» пластичні чи мовні прояви, внаслідок переживання пристрастей актором, не лише не здійснять ніякого враження на глядача, а й зашкодять художньому образу і правді характеру. Коклен не мав сумнівів, що талант і майстерність сценічного виконання проявляється не у підкреслених спалахах почуттів чи раптових емоційних поривах, а у «повному i постійному самовладанні» актора-людини. Разом 3 тим, Коклен не відкидає продуктивну силу натхнення у творчості, але зауважує, що актор суттєво збільшить вірогідність виникнення стану натхнення під час виконання ролі, якщо цьому передуватиме ретельна праця над образом, адже «щоб змусити зійти натхнення, потрібно спочатку підготувати себе до цього, тобто запліднити свій мозок розмислами і постійним вивченням своїх ролей» [2, 107-108].
Зрозуміло, що Коклен передбачає досконале володіння актором сценічною технікою, зокрема в галузі сценічного руху. Кожен жест і кожен рух персонажа актор повинен ретельно відпрацьовувати в системі двох координат: природності зовнішнього прояву характеру та врахування умовності сцени і оптичних законів $[2,111]$. Пошуки адекватної зовнішньої форми образу, за його твердженням, $є$ «наполегливою і завзятою працею», коли багато годин «можна просидіти над однією зморшкою» $[2,32]$. Тому робота першого Я актора 3 перетворення другого Я потребує усамітнення і повної концентрації на внутрішньому змісті характеру. Так само ретельно актор повинен працювати над пошуками мовної виразності свого героя. Як і зовнішність та ритмо-пластика вона має стати виразом характеру і внутрішнього світу сценічного персонажа. Силу мовної інтонації в акторському мистецтві, стверджує Коклен, не можна переоцінити, вона «невимірна і найживописніші ефекти $<\ldots>$ не можуть потрясти глядачевий зал так, як правильно інтонований вигук» $[2,33]$. У праці актора над мовно-інтонаційною партитурою образу першочерговою метою спрямування зусиль актора Коклен визначає артикуляцію, яка є одночасно i «абеткою», i «ввічливістю актора», і домінантою його мистецтва $[2,34]$, робота над якою має вдосконалюватися впродовж усього життя. Він позиціонує як аксіому думку стосовного того, що «на сцені не потрібно говорити так, як розмовляють у житті, — на сцені потрібно вимовляти», просто і природно, але неодмінно вимовляти [2, 44]. Вимовляти, уточнює Коклен, в акторському мистецтві означає надавати фразам їх справжнє значення, «проходити мимохіть тут, робити особливий наголос там; це означає розподілити рівні й опуклі місця, світло і тінь. Вимовляти - означає ліпити» $[2,45]$. Якщо актор говоритиме текст ролі як у житті - його мова буде безбарвною, але його вимовляння надасть фразам форму, гнучкість і образність, стане твором мистецтва. Одночасно він закликає акторів не втрачати почуття міри: 3 одного боку, не імітувати, під виглядом природності, невиразність і нечіткість мови, з іншого не доводити «чеканку мови» до крайності. Правильна артикуляція знаходиться посередині між «говорити» $\mathrm{i}$ «вимовляти», а головним завданням акторського мовлення $є$ донесення змісту слів до глядача. Необхідність бути «почутим» $[2,46]$ глядачем, окрім артикуляції, досягається не меншою мірою ритмом мови, а вміння актора знайти ритм, артикулюється Кокленом як основний закон сценічного мовлення. 
Робота актора над мовною характеристикою персонажа $€$ не менш копіткою, ніж робота над його зовнішньою візуалізацією. Актор повинен досконало володіти технікою сценічного мовлення - вмінням віднайти точну інтонацію, тембральне забарвлення, мовні модуляції голосу, щоб застосувати потрібний сегмент потенціалу своїх мовних ресурсів для характеристики сценічного образу. Коклен взагалі вважає, що цій частині другого Я актора «слід бути найгнучкішою, найбарвистішою, найбагатшою метаморфозами», щоб «навіть сліпі змогли його побачити» $[2,47]$, адже внутрішнє життя зображуваного персонажа сприймається глядачем через вербальні засоби виразності, можливо навіть більшою мірою, аніж через візуальні.

Як і будь-який актор, Коклен чудово розумів, що емоції або почуття першочергово проявляються через обличчя виконавця, вираз якого концентрується в очах, відбиваючи «світло і прозорість життя». Актор лише тоді зможе утримати інтерес глядача, коли те, про що він розповідає, відбиватиметься в його погляді, а отже, те, що за мить «зійде 3 вуст» [2, 54], спочатку має зосередитися в його очах. Це вочевидь доводить, що погляди Коклена на акторське мистецтво, поряд із необхідністю створення відповідної зовнішньої форми образу, передбачали і вияв потрібних почуттів, адже жодна, навіть найпростіша, емоція не може проявитися через обличчя, тим більше з'явитися в очах, якщо виконавець не зможе її викликати у потрібний момент. Напевно, і з цього приводу Коклен зауважував щодо вміння актора «регулювати витрати енергії», вольовим спрямуванням першого Я збуджувати і орієнтувати нервову систему на формування психічних імпульсів задля виявлення відповідних почуттів.

Спроба систематизувати процес роботи над створенням сценічного образу у Коклена націлена на пошуки шляхів досягнення актором головної мети - створення цілісного образу певної індивідуальності, який би відповідав вимозі життєвої правди і природності вияву почуттів. Його міркування у цій площині актуалізують також питання співвідношення правди і умовності у театральному мистецтві. 3 одного боку, Коклен наголошує на тому, що поза природою «ніщо не може бути прекрасним і великим» $[2,110]$, тому актор має спостерігати за ії проявами і запозичувати у неї й довколишнього життя все те, що стане у пригоді для правдивого зображення дійсності $[2,106]$. 3 іншого, розуміючи сутність мистецтва, він відзначає, що «неприкрашена природа справляє у те- атрі лише слабке враження», оскільки театральне середовище є особливим і потребує «пристосування до нього» $[2,111]$. Відтворення на театральному кону дійсності у іiї у цілковитій точності $€$ «немислимим», зазначає Коклен, і якщо «правда може інколи здаватися неправдоподібною, то саме на сцені...» $[2,67]$. Він пояснює це тим, що сцена змінює пропорції реальної дійсності; «рампа все перебільшує», і в такий спосіб «змінює закони простору і часу <...>. Те, що у житті представляється ниточкою, на підмостках перетворюється на мотузку товщиною у канат». Актора це стосується насамперед - він не може стати вище загальних законів мистецтва : «істина, пропорційність, гармонія обов'язкові для всіх» [2, 71-72]. Відтак природа у театрі, так само як і будь-якому виді мистецтва, стверджує Коклен, може бути відтворена «лише з певною ідеалізацією або підкресленістю, без яких не буває мистецтва» $[2,110]$. Вочевидь, його теза, що театр як мистецтво «має додавати до зображення дійсності аромат поезії, передчуття ідеалу» $є$ загальним постулатом, в контексті якого випад проти натуралізму стає цілком зрозумілим. Проте, називаючи натуралізм хибним, Коклен зауважує: «я за натуральність і проти натуралізму» $[2,64]$. Слід врахувати, що поняття «натуральність», «реалістичність» та «природність» для нього були тотожними. Питання співвідношення мистецтва і природи, умовності і правдоподібності у театральному мистецтві Коклен вирішує у діалектичній площині. Він не вірить у мистецтво, яке не узгоджується з природністю і також не бажає бачити на сцені «природність без мистецтва; все має йти від правди: все має прагнути ідеалу» $[2,67]$.

Коклен вважає помилковою думку тих акторів, котрі стверджують, що не можна добре зіграти те, чого не відчуваєш, і такий підхід до самопочуття в образі називає натуралізмом, адже за цією логікою актор має «напитися, щоб зображувати п'яного», по-справжньому засинати, аби хропіння здавалося натуральним тощо $[2,70]$. Тому Коклен застерігав акторів від «підкорення» ролі своїй індивідуальності та наголошував на необхідності перевтілення, яке досягається шляхом усвідомлення характеру персонажа - «найсуттєвішою» складовою акторської праці. У створенні сценічного образу, актор має шукати всі відповідники характеру свого героя, а «проникнення духом зображуваної особи» дасть можливість знайти його зовнішню форму, оскільки «фізична оболонка сценічного образу визначається внутрішньою сутністю особи, яка зображується» $[2,30]$. Так само 
як Шекспір і Мольєр, котрі не зображували у своїх героях самих себе і в них не відображаються, актор не повинен репрезентувати себе в образі, вважає Коклен. Натомість Шекспір і Мольєр «вибирали образи за певними спонуканнями, що витікали з особливостей кожного з них». Такий відбір образів, засобів виразності тощо відповідає «інтимнішим властивостям генія кожного з них, - i все це становить їхній стиль, манеру, і у цьому виявляється індивідуальність кожного з них». Враховуючи індивідуальну психофізику, темперамент, різний життєвий досвід акторів, Коклен орієнтує i акторів на подібний підхід до пошуку органіки сценічного образу і допускає привнесення людської особистості виконавця у створюваний ним образ, але за умови, що «печатка індивідуальності, якою позначена виконувана ним роль $<\ldots>$, буде розчинена в реальності образу...» $[2,80-81]$.

Надзвичайну унікальність самобутності шекспірівських і мольєрівських героїв, які «живуть власним і незалежним життям», Коклен пояснює й тим, що обидва драматурги самі були акторами, і це дало їм змогу «такою великою мірою вигнати власне я з своїх п'єс, які натомість глибоко позначені печаткою їхньої геніальності». 3 цієї причини Коклен закликає акторів, не лише постійно вивчати п’єси Шекспіра і Мольєра, а й так само, як вони, «невтомно вдивлятися в Природу, цю вічну Божественну комедію» $[2,81]$, запозичувати в неї різноманіття іiі проявів.
Таким чином, теоретичні міркування Б.-К. Коклена $є$ маніфестом акторської «школи удавання», яка грунтується на вивченні людської природи, знанні законів сцени та віртуозній акторській майстерності. Оскільки те, що відбувається на театральних підмостках не є реальним життям, у створенні ілюзії життя у сценічній коробці потрібно враховувати «неминучу умовність», адже театр - рампа, куліси, декорації - $\epsilon$ «сукупністю умовностей», складовою якої є й актор [2, 111], вважає Коклен. Щоб справити на глядача враження життєвої правдоподібності, потрібно по-мистецькому видозмінювати життєві умови, пристосовуючи їх до театрального середовища; театр лише створює ілюзію правдоподібності, тому критерії справжності тут $є$ інакшими, аніж у реальному житті, тому і актор без модифікації звичайних, «як у житті», пластичних і мовних проявів героя-людини не зможе вийти на рівень життєвої правди.

\section{Джерела та література}

1. Дидро Д. Племянник Рамо. Парадокс об актере / Дени Дидро ; [пер. с фр.]. - СПб. : Издательский Дом «Азбука-классика», 2007. — 224 с.

2. Коклен Б.-К. Искусство актера / Б.-К. Коклен ; [пер., вст. ст. и прим. А. Г. Мовшенсона]. — Л.-М. : Искусство, 1937. - 144 с.

3. Talma F. Reflexions Sur Lekain et Sur L'Art Theatral / F. Talma. - Paris : L. Tenre, Libraire, 1825. $68 \mathrm{p}$. 